\title{
Studying and Comparing Pictorial Drawings and Patterns of Chaharbagh School and Seyyed Mosque of Isfahan
}

\author{
Shahrbanoo $\operatorname{Khazan}^{1} \&$ Vigen Ghazaryan ${ }^{2}$ \\ ${ }^{1}$ Ph.D. Student, Department of history and theory of fine arts, Yerevan state academy of fine arts, Armenia \\ ${ }^{2}$ Professor, Department of history and theory of fine arts, Yerevan state academy of fine arts, Yerevan, Armenia \\ Correspondence: Shahrbanoo Khazan, Department of history and theory of fine arts, Yerevan state academy of \\ fine arts, Yerevan, Armenia. E-mail: vartohi5@yahoo.com
}

Received: September 27, 2016

Accepted: October 8, 2016

Online Published: October 17, 2016

doi:10.5539/mas.v11n1p102

URL: http://dx.doi.org/10.5539/mas.v11n1p102

\begin{abstract}
Background/Objectives:The construction of Chaharbagh School and Seyyed Mosque of Isfahan has one century difference. In these 2 places the botanical and geometrical drawings are shown significantly and separately by having spiritual simplicity available in ornaments of tiles; however, in the infrastructure of moscuqe-school there is integration of different drawings shown as pile of colors and drawings without having specific purpose that are drawn on wall with complete details.
\end{abstract}

Methods/Statistical analysis :In this project, it is benefit from library and field studies by using observation and the drawings of tile of work of Chaharbagh School and Seyyed Mosque of Isfahan are evaluated and compared and the properties of drawings of each section is analyzed and finally a table is offered for their comparison.

Findings:In continuation of research, it is specified that generally the ornaments and drawings available in places belonging to Safavid dynasty, are originating from beautiful nature that are differently revealed in layout of walls, cloths and other things. The space of painting is more free and in the background there is mixture of tableau and space. Moreover, these mixed drawings are inspired from nature and beauty that not only does not lead to fatigue of eye and soul, but also refresh the human soul. Most of the artists during Qajar dynasty by self-learned method and by means of picture attempted to be familiar with architecture of western culture.

Application/Improvements: Therefore, maybe it is more logical that merging these 2 systems is mainly unwanted and as a result of influence of ancient tradition from one hand and lack of being familiar with scientific and academic principles of European art.

Keywords: tile working drawing, chaharbagh school, seyyed mosque of isfahan

\section{Introduction}

When Shāh Abbās the Great or Shāh Abbās I of Persia ascended the throne, the Iranian arts became popularize and this issue paved the way for establishment of Isfahan School as the last ray of noble Iranian Persian miniature. During decline and dispersion of art and disappointment of artists supported by capital of Safavid dynasty has interesting story that finally leads to freedom of artistic basics from restriction of kings and its popularization among public society. Upon collapse of Safavid dynasty and establishment of Afsharid dynasty, death of Nader and chaos in Iran and when Mohammad Karim Khan Zand ascended the throne and dominance of Mohammad Khan Qajar and establishment of Qajar dynasty following up collapse of Zand dynasty, Persian miniature was gone under many changes and evolutions from viewpoint of materials, social approaches and method of offering techniques. In spite of significant attention of kings of Safavid dynasty for the art and artist, Karim Khan Zand neglected artists; therefore, artists who lost the long term economic prosperity of Safavid dynasty, had no choice for moving toward lower classes of society and some educated aristocrats specially middle class of society. The interesting point is that in addition to changing different Iranian Kings, it is to be noted that since Safavid dynasty gradually the European painting entered into Iran and the Iranian artists applied from new tools including: color, oil and canvas and doubtlessly due to influence of this process the knowledge of applying color on western mode entered into Iranian style of painting. Thus, this issue is raised that there were some differences in the paintings with respect to function and application of color and design in comparison to previous ages. In Islamic architecture upon executing the skeleton of building, it is mainly focused on domestic 
ornaments and façade of building and this unity is available among different aspects of Islamic architecture in different areas of world (Marzban, 1986). The Iranian art ornamental drawings specially tile working is divided into 5 sections including: botanical, animal, human based, geometrical and ornamental drawings. Chaharbagh School-Mosque from geographical point of view is located at Chaharbagh Street and was constructed during kingdom of Shah Sultan Hossein Safavi as the ultimate Safavid king. This building was constructed on 1116 according to lunar calendar and its construction was lasted to 1126 according to lunar calendar. This building is also famous as Sultani School, Madar Shah School, Chaharbagh School and Imam Sadegh School; nevertheless, at the present time is it famous as Chaharbagh School among inhabitants of Isfahan. This school has area of 8550 square meters and the area of its yard is 3900 square meter. The northern part of this school is tall market and the eastern part is Abbasi motel (part of ex-caravansary). Dome, Minaret, Minbar, Mihrab, Shabestan, patio are all referring to this fact that this building is a mosque and the surrounding rooms in 2 floor patios, libraries, studying hall are all referring this fact that this building was school. Another mosque-school is Seyyed Isfahan that is among historical buildings constructed during middle $13^{\text {th }}$ century and Fath-Ali Shah Qajar. This building was constructed by Ayatollah Haj Seyed Mohammad Bagher Shafti and at the present time is regarded as one of the valuable Islamic building that is souvenir of artists during Qajar dynasty. This building was constructed in a rectangular land having total area of 8075 square meters in Seyyed Mosque St, in Bidabad neighborhood of Isfahan that is among old-important neighborhoods of that age and next to Bidabad small market of Isfahan. The construction process of this building was begun by Ayatollah Haj Seyed Mohammad Bagher Shafti who was among great clergies of Isfahan and the tile working process of this building was lasted to the end of second half of $13^{\text {th }}$ century. Part of the ornaments of this building was completed by Haj Seyyed Asadollah the son of Ayatollah Haj Seyed Mohammad Bagher Shafti upon his death and it seems that part of its ornaments are still remained incomplete. This research attempts to study the differences in drawings among Chaharbagh School and Seyyed Mosque of Isfahan.

\section{Botanical Drawings}

\subsection{Bindweed Arabesque and Angelica Flower}

Rotation and dynamic movement of Arabesque and fresh Angelica Flowers play key role in ornaments of religious buildings and it is example of desired paradise. The main pattern in Chaharbagh school-mosque is geometrical drawings, Arabesque and Angelica drawings in dome and some triangles in patio and Mihrab that have many thin branches and abstract flower design mainly on Turquoise blue (color) or Ultramarine color background.
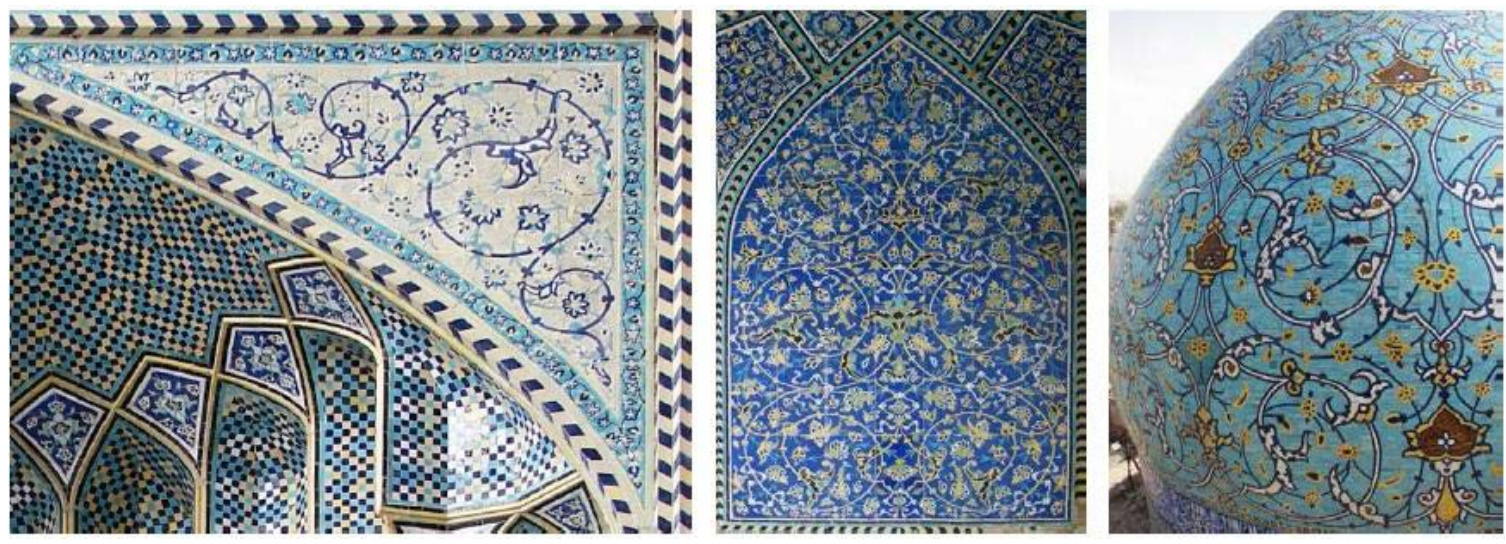

Figure 1. Arabesque and Angelica drawings of Chaharbagh school-mosque

Generally, in the structure of botanical drawing the main structure consists of Arabesque drawings that are more stable, strong and thick from visual point of view and the flower and leafs of Angelica are located between Arabesque drawings; nevertheless, during Qajar dynasty the drawing of vase were mainly inspired from natural elements including: fruits, flowers, animals and birds (Makinejad, 2008). In Seyyed mosque-school the main drawing is Arabesque and Angelica not the geometrical drawing mainly with large rotation and relative thick branches and background full of flower including: red flower and Irises that are drawn very naturally with different designs such as: landscaping, picture of fruit and similar items are regarded as imitation of European ornaments by having yellow, green and blue background. Angelica Flower due to being located adjacent to natural flowers have lost their appearance and by having full color and drawing, there is no independent identity 
of Arabesque and Angelica (Figure 2)
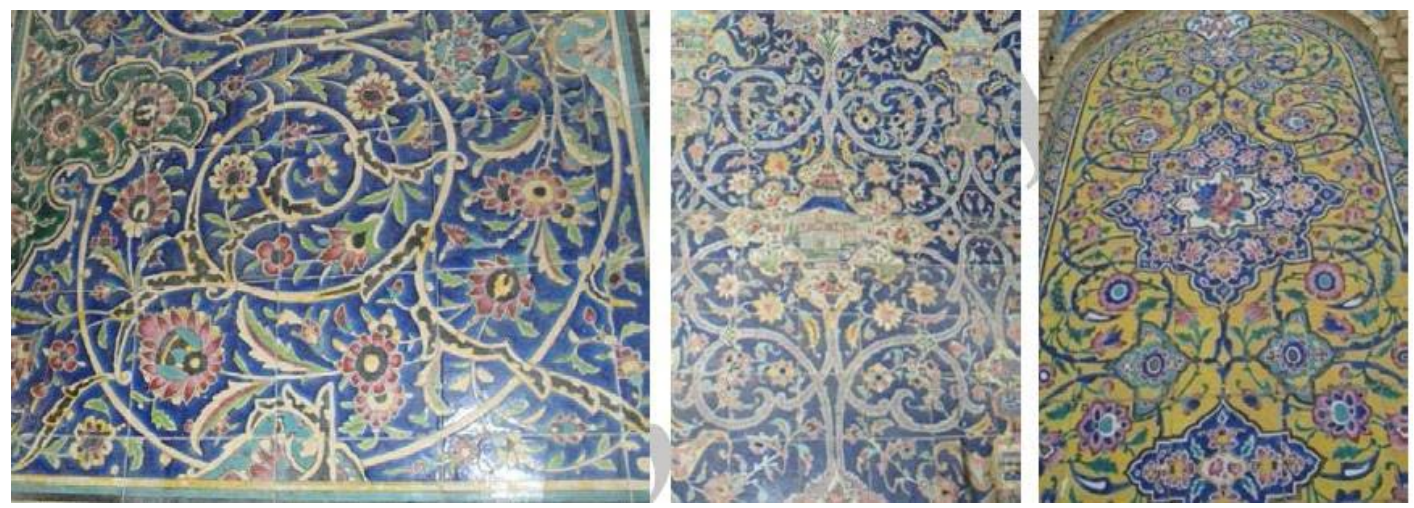

Figure 2. Arabesque and Angelica drawings of Seyyed mosque-school

\subsection{Vase}

The drawing of vase is applied in ornaments of tile working and stonemasonry and studying the drawing of stonemasonry vase is very significant and important. The stonemasonry drawing on marble of Chaharbagh school-mosque are very simple; nevertheless, in the vase drawing of Seyyed mosque-school there are some very delicate stonemasonry. Generally, the vase drawing during Safavid dynasty is very simple and there are a few ornaments from botanical drawing (Figures 3 and 4).
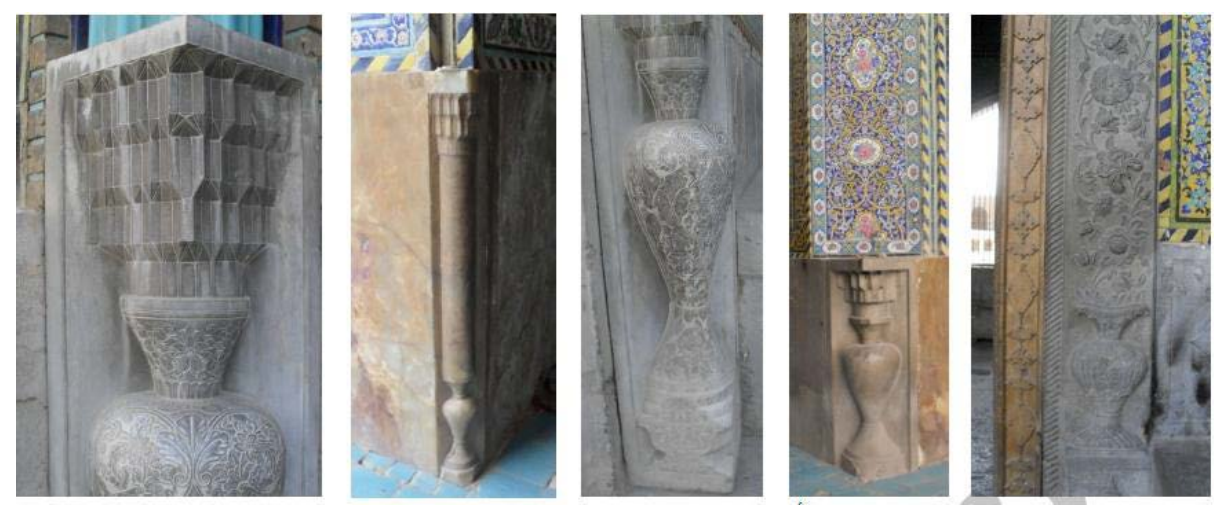

Figure 3. Vase drawing of Seyyed mosque-school
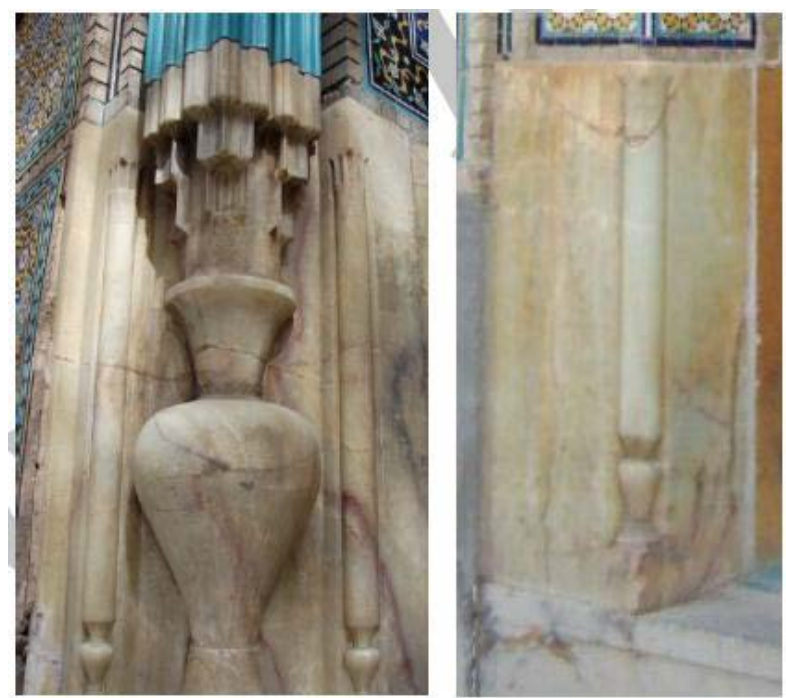

Figure 4. Vase drawing of Seyyed mosque-school 
In addition to application of vase drawing in stonemasonry, at Seyyed mosque-school there is other form of vase drawing including: vases with full flowers on tile and plaster that is not available in the ornaments of Chaharbagh school-mosque.

It seems that the term "ornament" is applied with 2 general and completely separate concepts at Islamic art i.e. the first one is ornament with the concept of beauty, layout and general arrangement in a set that refers to product and general result of product and in Latin is famous as harmony or harmonic. The second one is ornament with the concept of an attitude, style and method of artistic work including: architectural ornaments, wall ornaments, plaster working ornaments, painting and inscription ornament that generally is famous as "graffiti". For example, consider this sentence: This style of ornament has a type of aesthetics purpose that saves wall from being empty (Konel, 2004). During Qajar dynasty, the tile was regarded as painting canvas for drawing mainly different natural painting and patterns by the artists (Marzban, 1986) and focusing on delicacy and details. The vase drawing during Qajar was faced with limitation of natural based elements including: different flowers specially, red flower, Irises, grapes and fruits. During this age, the role of vase is executed with complete naturalism viewpoint. "Generally, ornaments during Qajar dynasty had specific importance and most of ornaments were mainly influenced by western culture. Most of the artists during this age were based on western art, naturalism point of view and reflecting objective reality by influencing from vase tile drawn with full detail that best reveals the ornaments (figure 5).
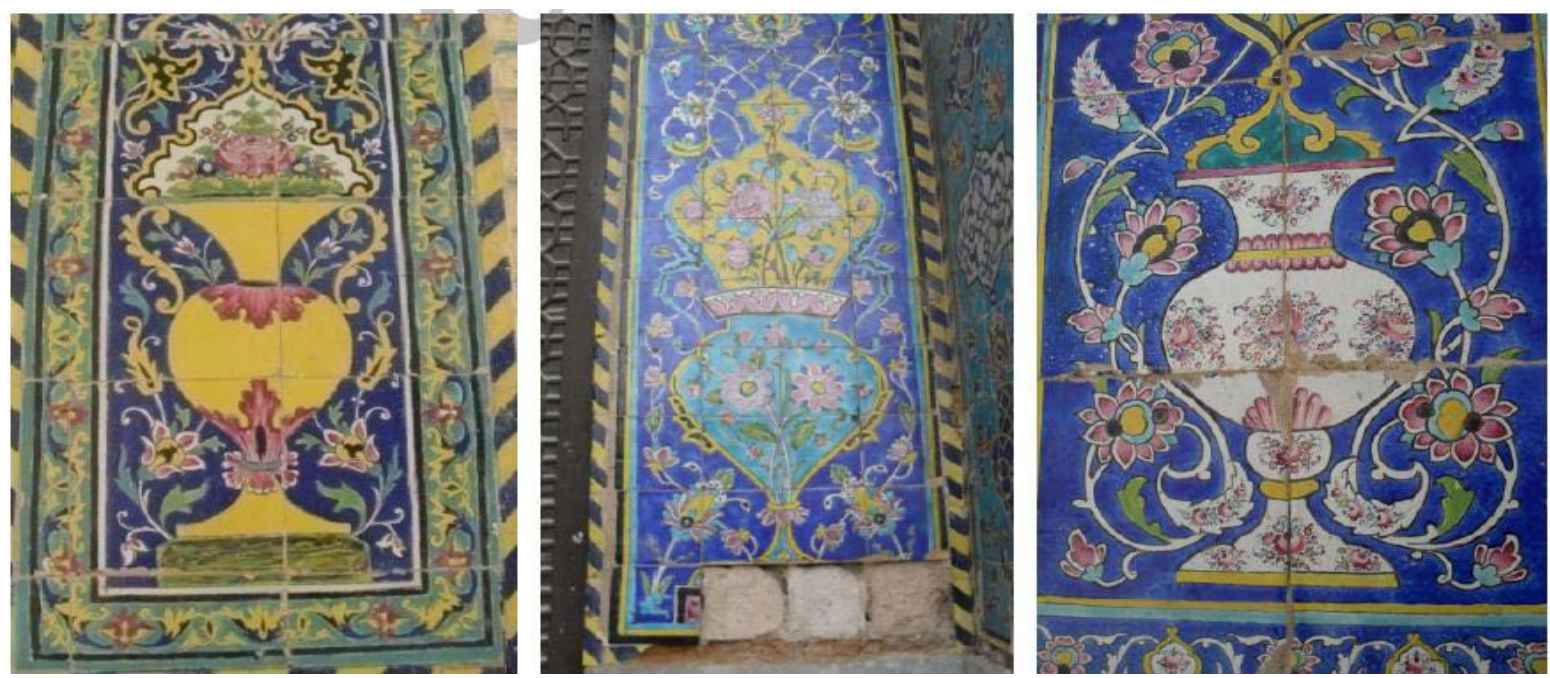

Figure 5. Drawing, flower and vase of Seyyed mosque-school

\subsection{Plate Bowl}

The modern history of Iran is the history for dominance of new western civilization over ancient Iranian civilization, either it is prosperous or destructive and in our point of view toward evolutions of art especially architecture during Qajar dynasty there is no significant difference (Bani, 2010). Architecture during Qajar dynasty is a form of duality i.e. from one hand this architecture is bounded to its previous Iranian traditions and from other hand it is influenced by western architecture (Marzban, 1986). Through deeply studying the art of Qajar dynasty we found out that the artists of this age followed up the process of Iranian culture in this way i.e. they converted the foreign culture not their themselves and this is regarded as one of the most valuable approaches of art during Qajar dynasty (Bani, 2010). By having more exact look, it is revealed that drawing on pots full of red flower and Irises with natural scenery is extracted from postal card imported from Europe and sometimes it is replaced by inside of ovular form frame full of yellow branches and leafs that are all unprecedented pictorial themes of tile working (Ferei, 1995). In addition to drawing of flower and vase, one of the drawing that was available under influence of western art including: flower school and Shiraz poultry was a drawing called "plate bowl" i.e. there was a bunch of flower inside of a bowl with very detailed and ornamental drawing that some of its samples are available in Seyyed mosque-school. 

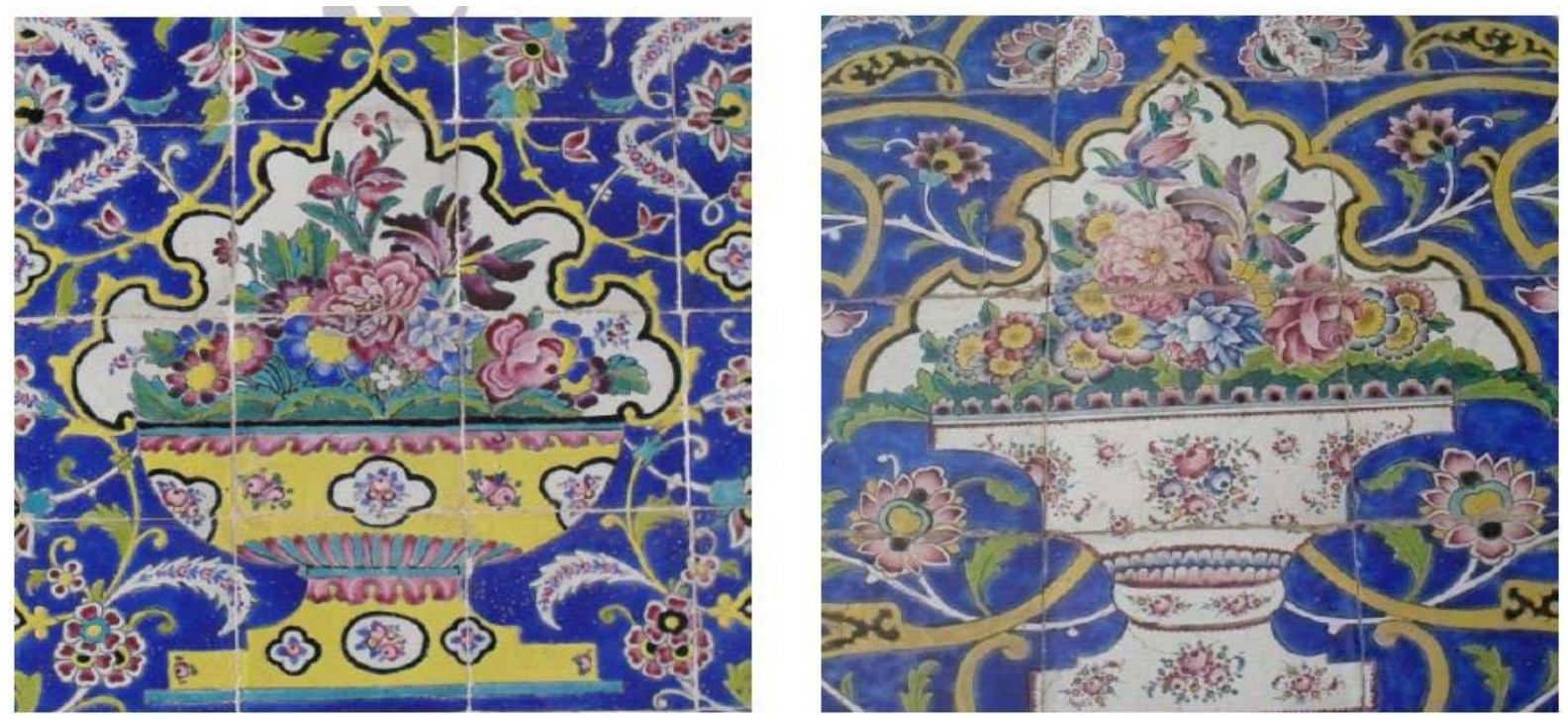

Figure 6. Plate bowl drawing in Seyyed mosque-school

\subsection{Grapevine and Grape}

The ornamental drawings of buildings through entrance of Islam to Iran and negation of Iconolatry, the drawings moved toward botanical and geometrical drawings and different botanical and beautiful drawings were introduced mainly showing rotating drawing including: Tendril and according to belief of ancient Iranian, the grapevine is the symbol of imperial dynasty. In fact, grapevine is the symbol of Christianity and Dionysus in relation to grapes by having some common points. A rolled paper of grapevine has aspect of Dionysus temple and this drawing with its worship was influenced the Asia; nevertheless, its Iconolatry was eliminated. In the Christian art and architecture there is this belief that ancient grapevine is the symbol of Jesus (Hall, 2001). The drawing of grapevine and grapes in Chaharbagh school-mosque is observable as rotating Arabesque in different ornaments of dome, patio, Mehrab and similar places; however, in the drawing of Seyyed mosque-school in addition to Arabesque form, there is nature based form that is not available in the ornaments of Chaharbagh school-mosque.
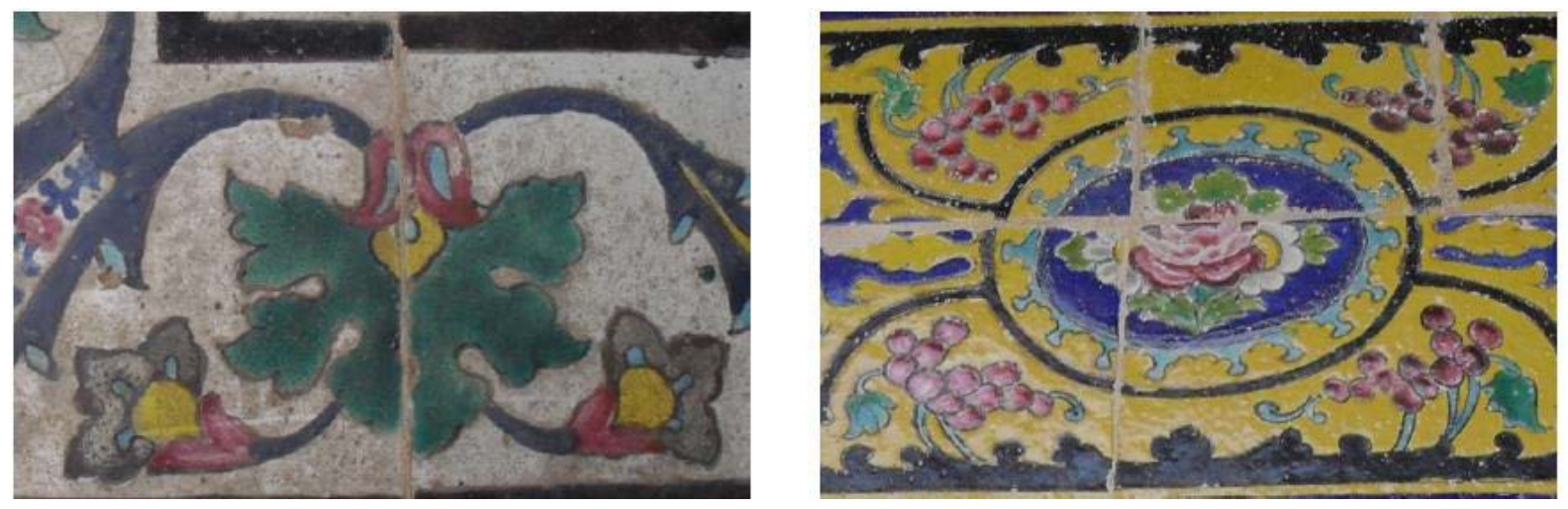

Figure 7. Grapevine and grape drawing at Seyyed mosque-school

The drawings of grape branches are like the drawing of stamps, photos, postal cards that are used at tile working drawings of Seyyed Isfahan mosque-school by having ornamental application and is symbol of influence of western culture and art.

\subsection{Human Drawing}

Human drawing is among the most common and specific property of tile working during Qajar dynasty. The main drawings are including: winged angels, photos of men and women at different positions (standing up, 
sitting down) human body or the body of different animals, semi-nude body and such themes. The human drawing during Islamic age were mainly faced with some limitations; meanwhile, the wallpaper paintings on wall of palaces, houses of aristocrats and governmental buildings during Safavid dynasty are visible; nevertheless, these photos were not present at religious buildings. It is to be noted that the human body in the religious photos of house of worship (Hosseinieh), Tekyeh (place of mourning) and public drinking place of Qajar dynasty were famous as "Tea house painting" mainly were photos of saint Shiite Imams, Hazrat Abolfazl, Hazrat Ali Akbar and ascension of Prophet Mohammad. Nevertheless, in tile working of Chaharbagh school-mosque and Seyyed Isfahan school there is no human drawings.

\subsection{Architectural Sceneries}

The architectural sceneries are among drawing that following up the invention of photography and entrance of European postal cards to Iran, were entered into tile working and plaster working of Iran. The architectural sceneries were mainly applied in Qajar dynasty and this issue is significant in the ornements of Seyyed mosque-school. Sometimes these sceneries had 3D and penumbra mode that reveal the influence of sceneries from photography. There are different forms of architectural sceneries including: urban, church, palace, castle, mosque, factory and tent (Alireza, Maziar, Majid \& Saeed, 2015).
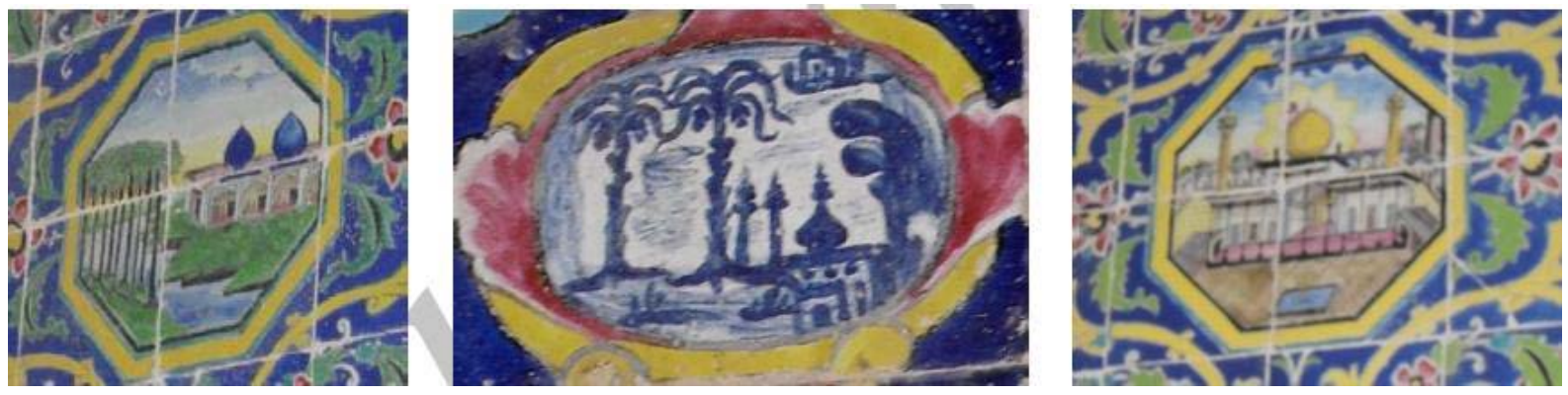

Figure 8. Architectural sceneries (mosque) at Seyyed mosque-school
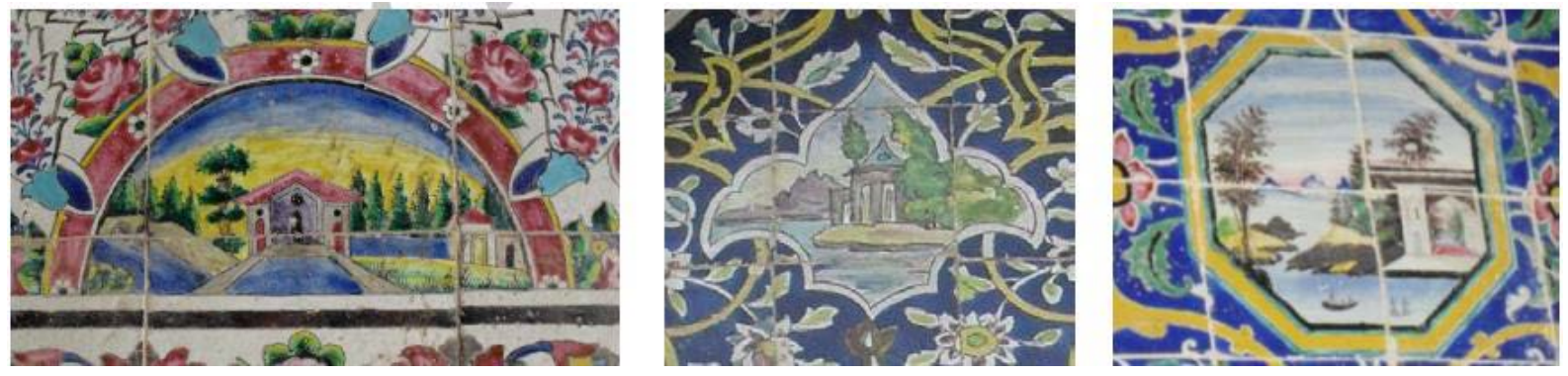

Figure 9. Architectural sceneries (nature) at Seyyed mosque-school
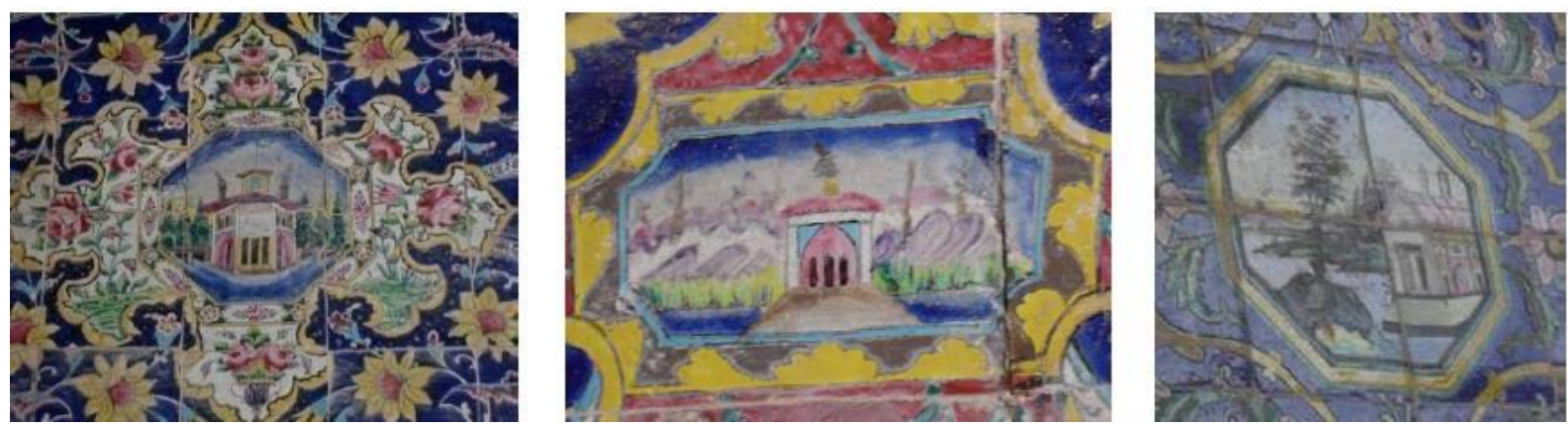

Figure 10. Architectural sceneries (nature and factory) at Seyyed mosque-school

\subsection{Geometrical Drawings}

Chaharbagh school-mosque is set of geometrical drawings, knots and in other words it is a pictorial encyclopedia 
of different diverse abstract and geometrical forms that is mainly visible at internal and external part of school by different methods and the main geometrical drawings applied at Chaharbagh school-mosque in comparison to the geometrical drawing of Seyyed mosque-school has more detailed and delicate
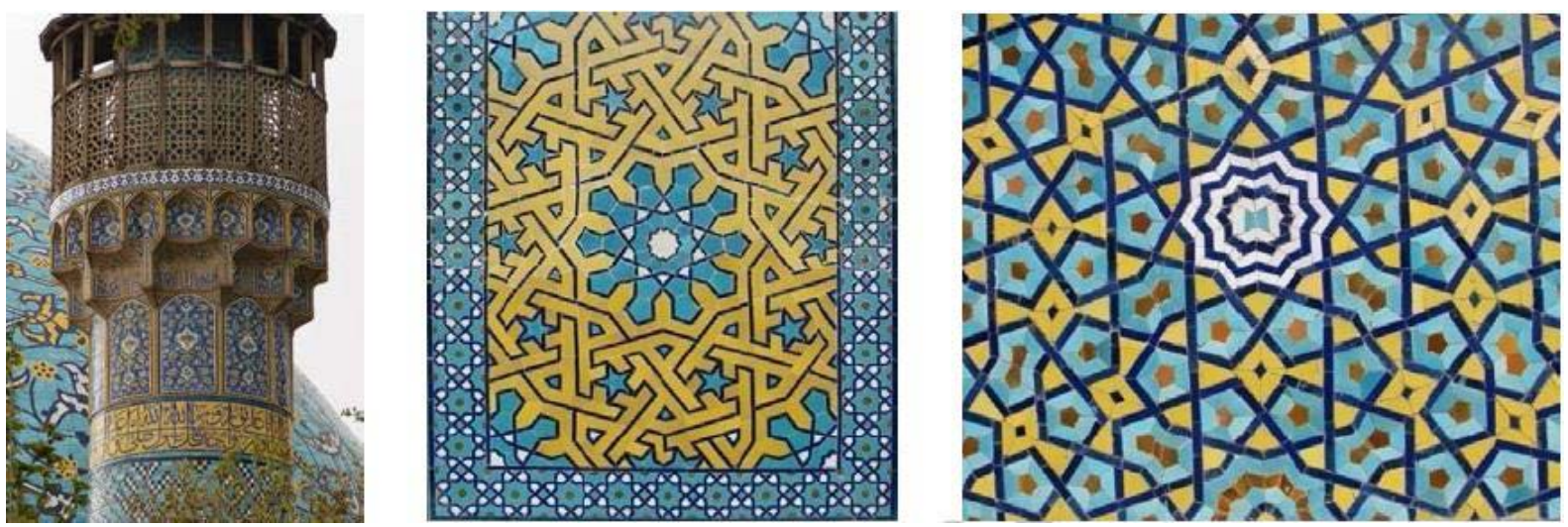

Figure 11. Geometrical drawings of Chaharbagh school-mosque
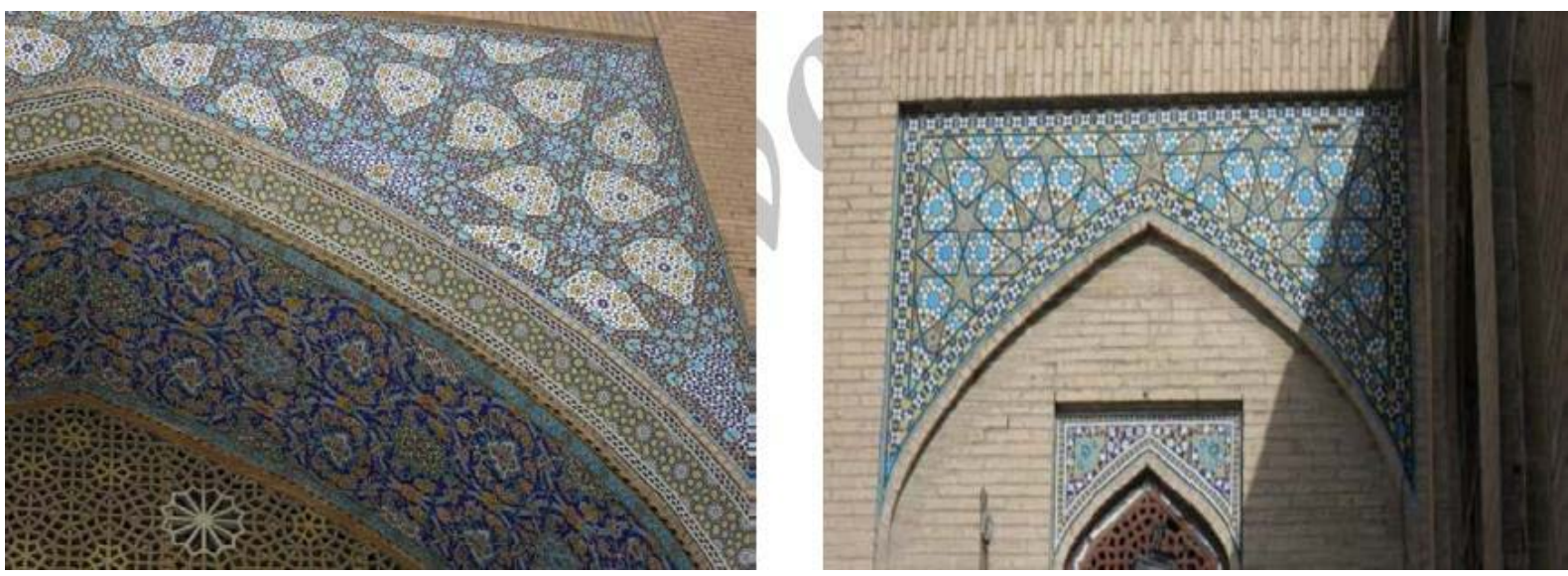

Figure 12. Geometrical drawings of Seyyyed mosque-school

In contrast, the geometrical drawings of Seyyyed mosque-school has less share in total ornaments and moreover, in some geometrical drawings of both buildings, there is abstract drawing of flower.
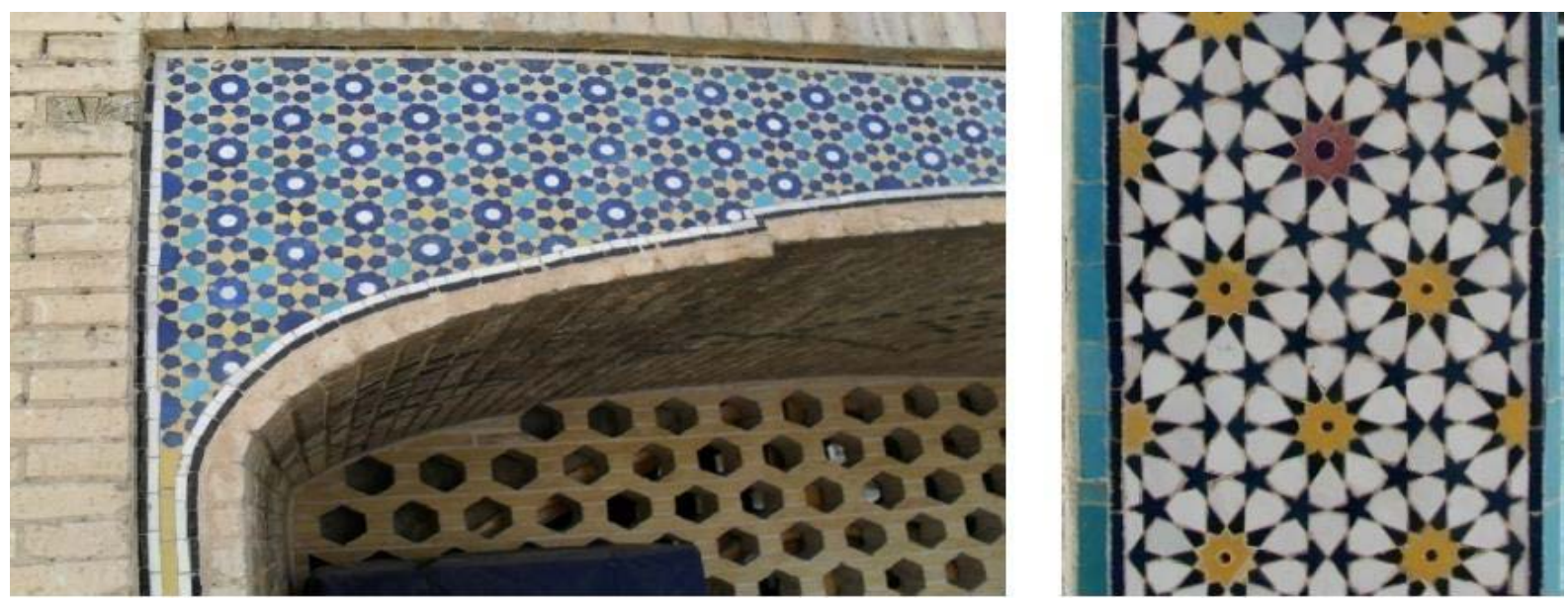

Figure 13. Geom(right hand) and Seyyed mosque-school (left)etrical drawing with abstract design of flower at Chaharbagh school-mosque 


\section{Ornamental Script}

\subsection{Kufic Bannai Script}

The main ornamental script during Safavid dynasty was Bannai and Thuluth; in which, in compliance with spiritual-religious aspect and having several professors, these scripts were at center of attention. During Qajar dynasty through advancement of Nasta līq script (Nastaleeq) most of the inscriptions were written by this script. One of the properties of Kufic Bannai Script during Safavid dynasty was attention and focus on geometrical Rhombus and square shape as frame and single geometrical drawing at composition that is significantly obvious at ornaments of Chaharbagh school-mosque (figure 14 and 15).
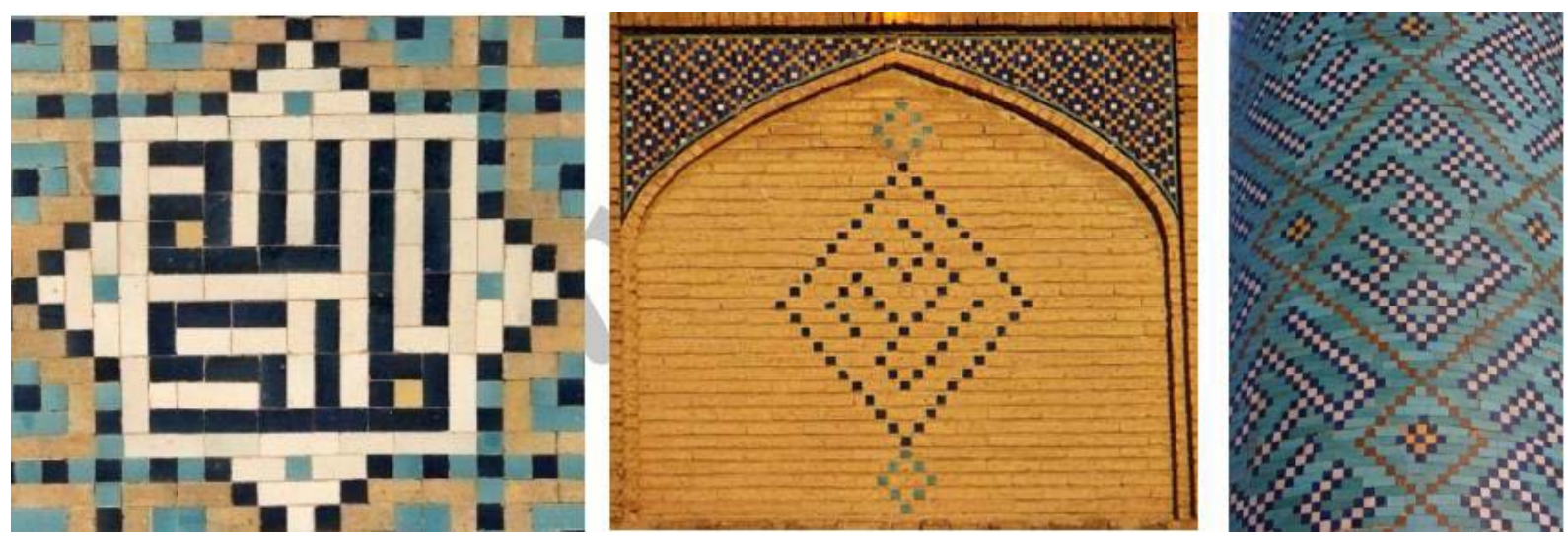

Figure 14. Kufic Bannai Script in Chaharbagh school-mosque
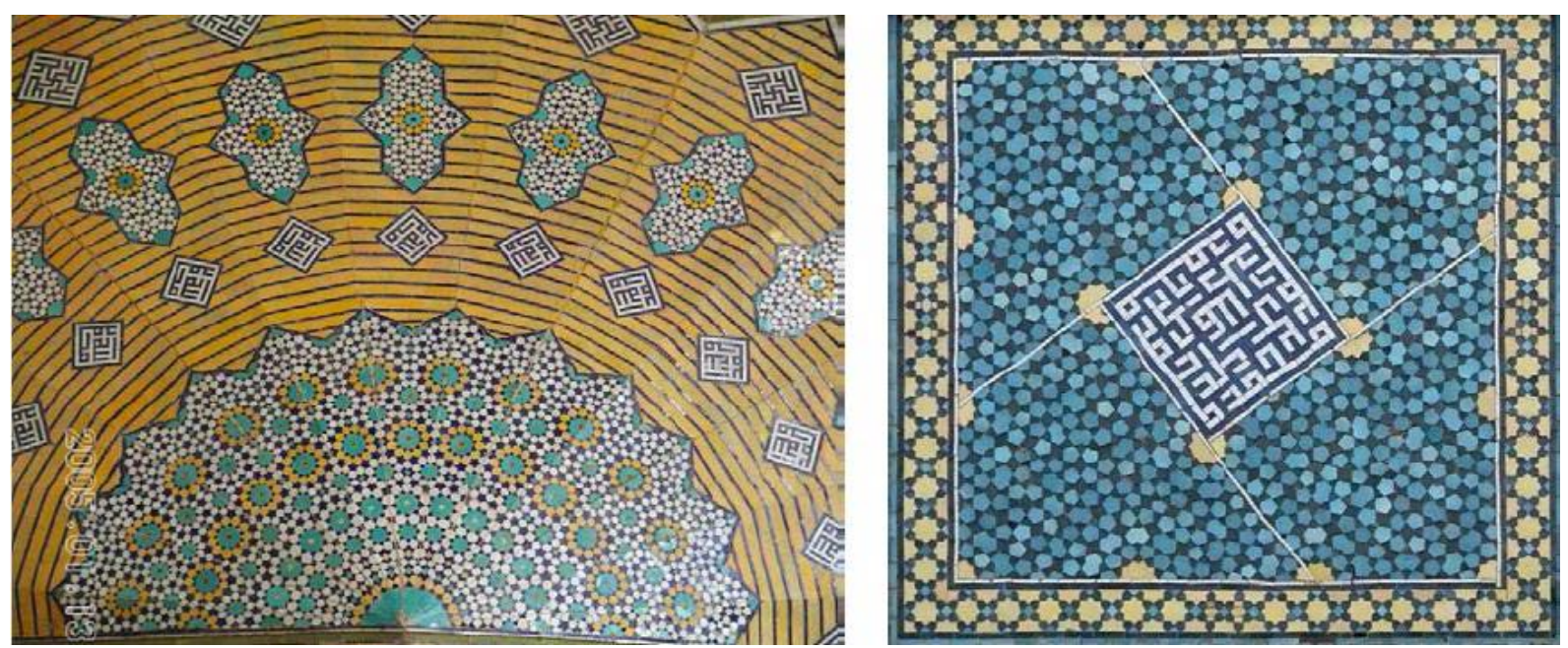

Figure 15. Kufic Bannai Script in Chaharbagh school-mosque

One of the most important points for compatibility of images of Kufic Bannai Script during Safavid and Qajar dynasty is that these scripts were applied in the inscriptions of Safavid dynasty without using any dots; nevertheless, in most of the inscriptions during Qajar dynasty, the dots were applied as page filling factor (Sarafzadegan, 2001). 

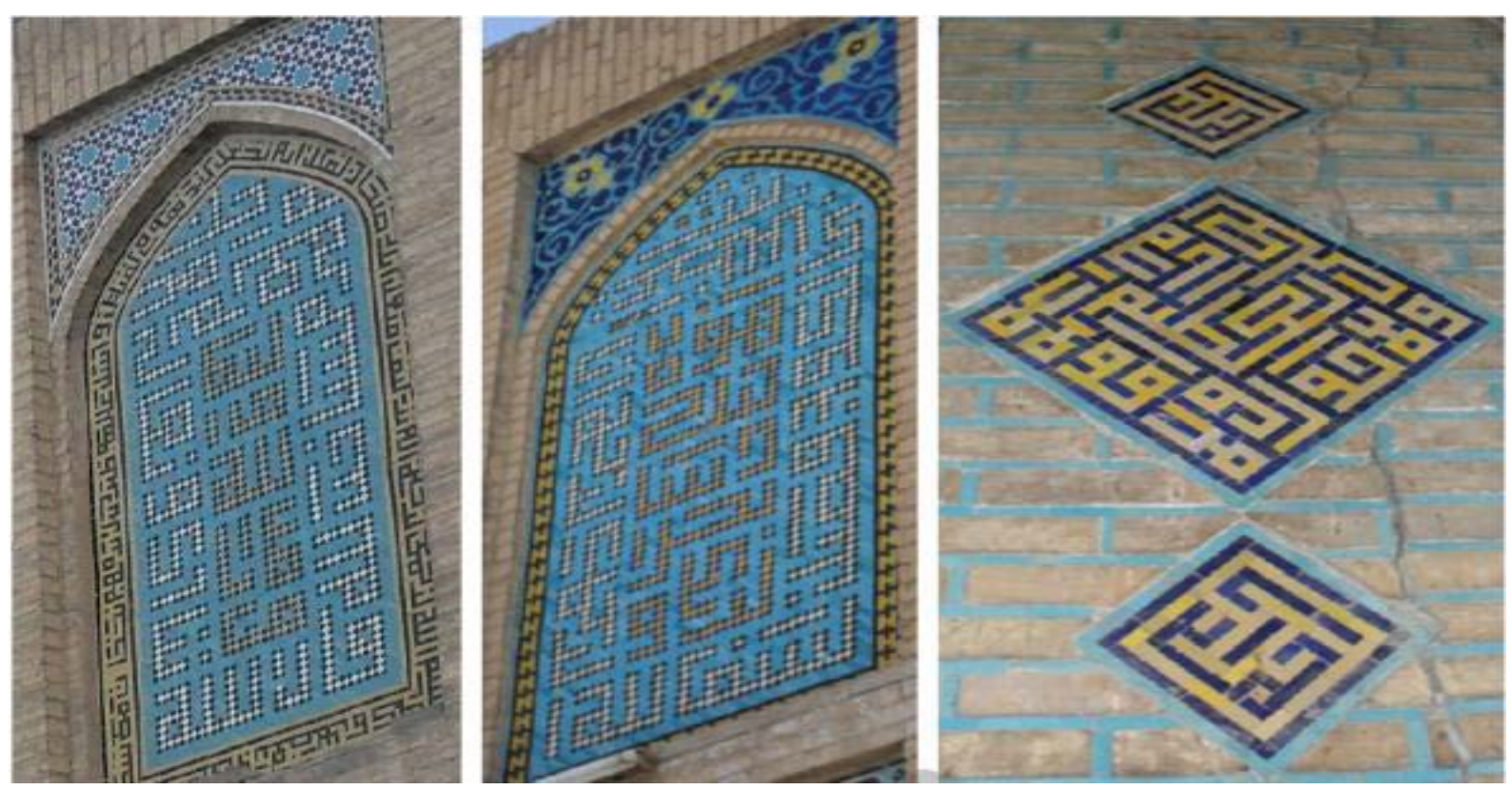

Figure 16. Kufic Bannai Script of Seyyed Mosque-School

The main Kufic Bannai Script applied in the inscriptions of Seyyed mosque-school is generally located at eastern and western part of building and in the inscriptions on top of the rooms of $2^{\text {nd }}$ floor that is mixture of several Kufic Bannai Script with different colors including: white, yellow in ornamental yellow and black frames with triangles with Arabesque and geometrical ornements and rowlock bricks (Assari \& Mahesh, 2011). Meanwhile, inscriptions of Chaharbagh school-mosque are applied with both Kufic Bannai Script and with single color.

\subsection{Thuluth}

The Thuluth script is applied in both building at suburb of patios, back parts, top entrance, Tholobate and similar places. The Thuluth script applied in Chaharbagh school-mosque has high stretch and altitude that leads to high compression and difficulty of its reading (figure 16); nevertheless, in Seyyed mosque-school the Thuluth script has less compression and stretch and it is easier for its reading (Figure 17).
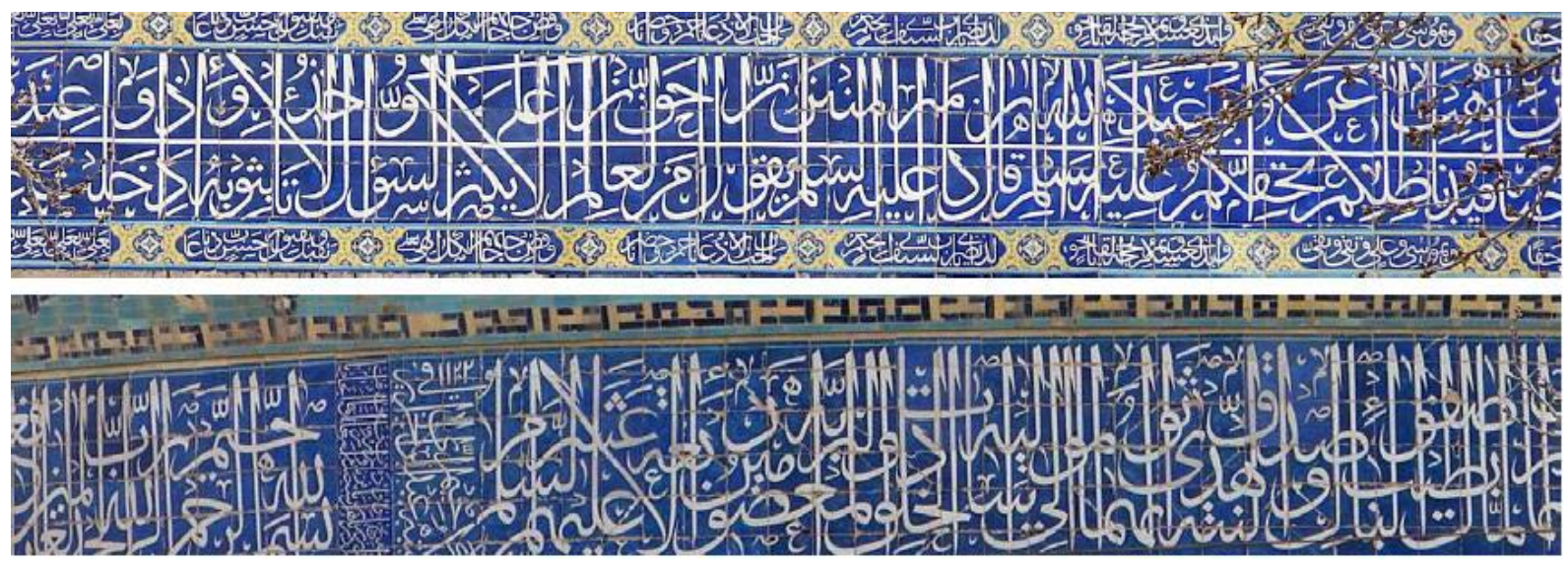

Figure 17. Thuluth script at suburb of patios and Tholobate at Chaharbagh school-mosque 

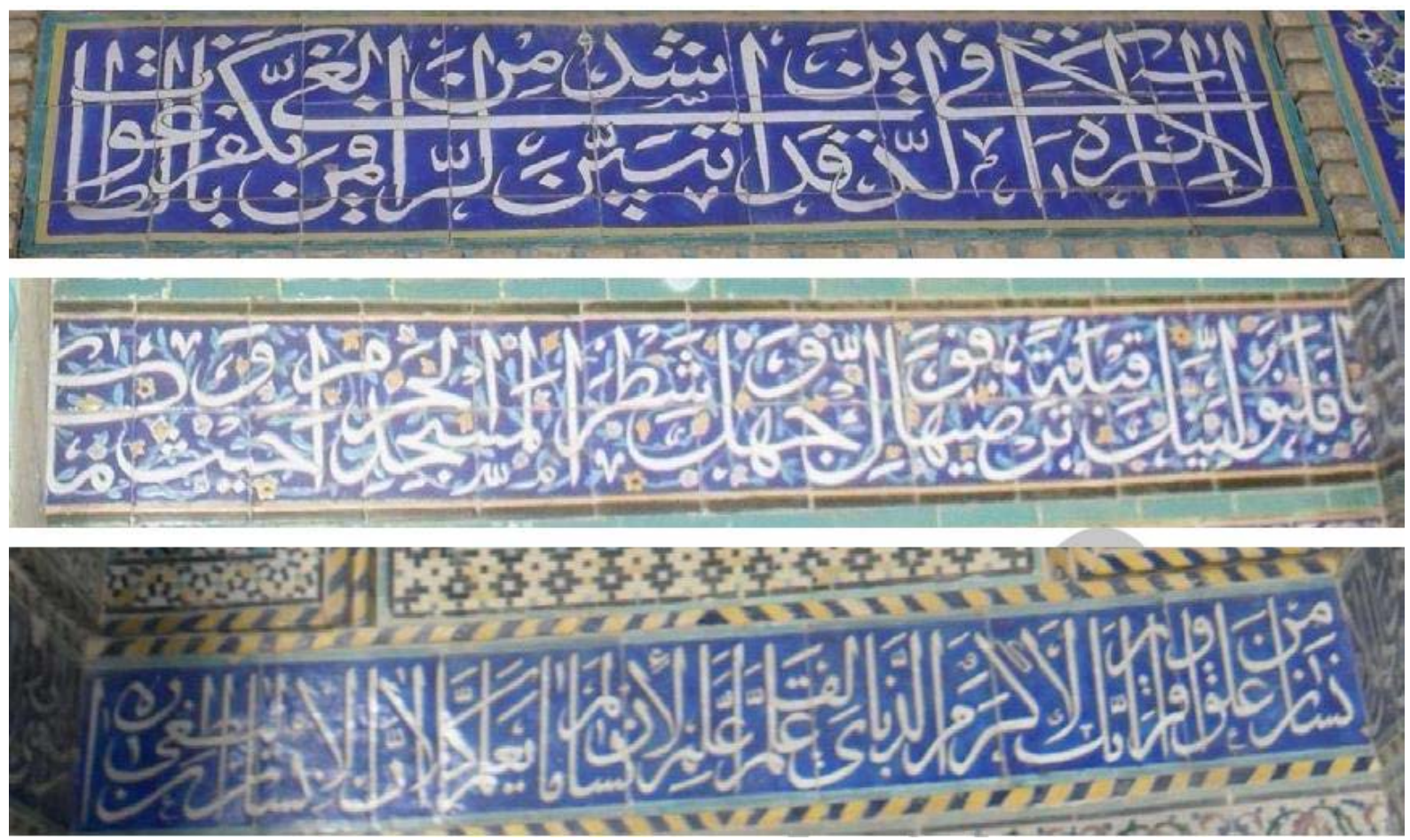

Figure 18. Thuluth script at Seyyed Mosque-School

The background of Thuluth script in both buildings is free from ornaments and the line is merely used at pure and noble. The empty spaces are filled with diacritic and the background of some inscriptions is filled with movement of botanical drawing with mild colors. Moreover, the scripts of inscriptions of both buildings have applied from white or yellow colors with ultramarine background. The Thuluth script of both buildings has applied from divine names, verses of Quran.

\subsection{Nasta 'ìq script (Nastaleeq)}

The Nasta līq script (Nastaleeq) is completely Iranian script that is symbol for unity and cultural identity of Iranian people against the influence of western art during Qajar dynasty. Although this script was famous during Safavid dynasty, there is only a few samples of this script in Chaharbagh school-mosque by having separate frame located within a single direction (figure 18); nevertheless, this script is widely applied in Seyyed mosque-school; for example, at top of rooms of clergies this script is applied with some ornaments and like the frame of Chaharbagh school-mosque, the script is written with inner white color line and ultramarine background and ornamental elements. The text of such written is in the way of eulogy of Prophet Mohammad and Imam Ali.
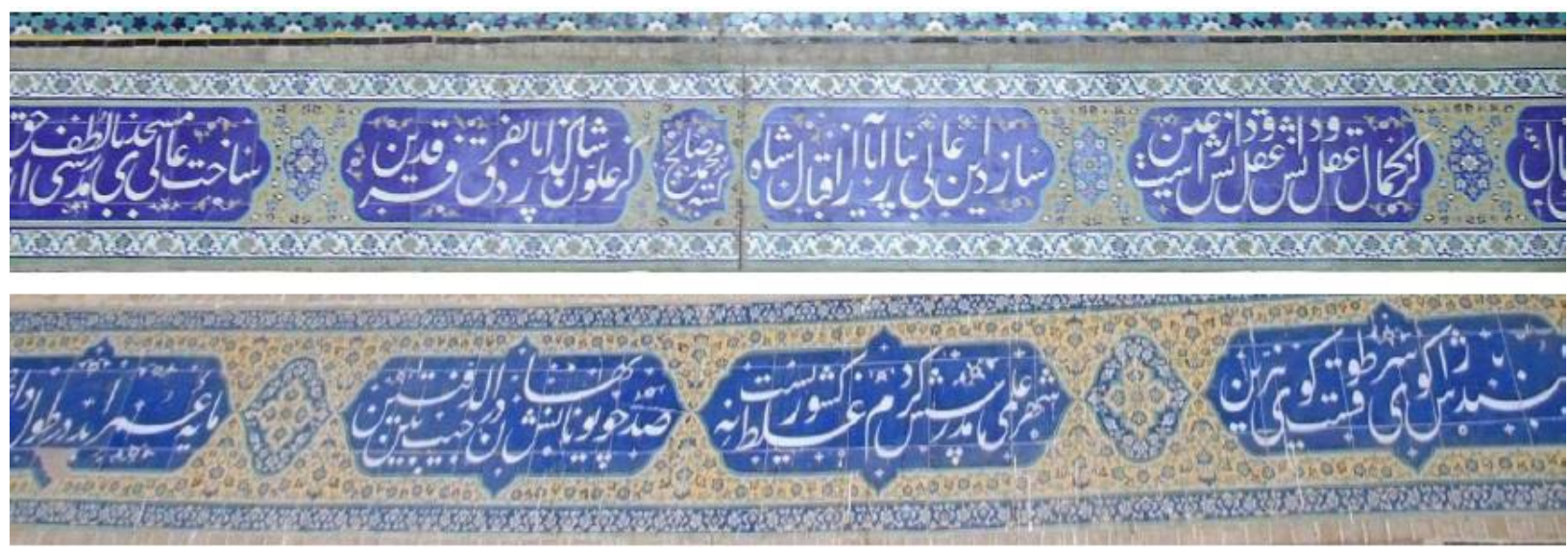

Figure 19. Nasta 'līq script (Nastaleeq) at Chaharbagh school-mosque 
Other examples for application of Nasta 'līq script (Nastaleeq) at Seyyed mosque-school is Persian translation of prays that one sample is visible at north Vestibule (architecture) for Hadith, saint names, signature of professors, description and date of constructing building (figure 19).

\section{Discussion \& Conclusion}

According to the studies and comparison between drawings of tile working related to Seyyed mosque-school and Chaharbagh school-mosque the following conclusions are inferred:

In Chaharbagh school-mosque it is applied from botanical and geometrical drawing that each of them are separate and specified by having simple-spiritual mode in the ornaments of tile; nevertheless, in the Seyyed mosque-school, it is mixture of different drawing that is applied at mixture of colors and drawings without any specific purpose with very details spread over the wall, in Seyyed mosque-school it is less applied from Iranian geometrical and botanical drawing and instead it is applied from Arabesque, natural drawing, natural flowers, architectural sceneries, fruits (grapes), western drawings of flower, vase, plate, bowl that is influenced by western culture. Most of the artists during Qajar dynasty, most of the artists during Qajar dynasty were mainly influenced by western culture and architecture; therefore, maybe it is logical that merging these 2 systems is somehow unwanted and as a result of influence of ancient tradition form one hand and lack of enough familiarity with scientific and academic principles of this European art. Thus, regardless from its comparison with European art, it has unique properties. The main script for inscriptions of Chaharbagh school-mosque is Thuluth- Kufic Bannai Script with principal theme of Hadith, verse, Surah and Quran that in compliance with their style of execution, it is somehow difficult for reading them; nevertheless, in Seyyed mosque-school due to style of writing, it is easy for reading the script; since, the main script is Nasta 'līq script (Nastaleeq) that is applied for translation of prays, verses, saint names, signature of professors, description and date of constructing building (table1).

Table 1.

\begin{tabular}{lll}
\hline Types of Drawing & Seyyed Mosque-School & Chaharbagh school-mosque \\
\hline Botanical & $\begin{array}{l}\text { Delicate with full ornaments, details } \\
\text { based on nature }\end{array}$ & Simple, few ornaments and abstract \\
$\begin{array}{l}\text { Human and animal } \\
\text { Architectural }\end{array}$ & $\begin{array}{l}\text { None } \\
\text { sceneries }\end{array}$ & Wide application \\
$\begin{array}{l}\text { Geometrical drawing } \\
\text { Ornamental lines }\end{array}$ & $\begin{array}{l}\text { Highly applicable and complicated } \\
\text { Easily readable }\end{array}$ & $\begin{array}{l}\text { Not seen } \\
\text { Simple with few ornaments } \\
\text { Difficult readable }\end{array}$ \\
\hline
\end{tabular}

\section{References}

Bani, M. A. (2010). Iran contemporary architecture (a struggle between tradition and modernity), Honar Memari Gharn publications, Tehran.

Ferei, R. W. (1995). Arts of Iran, translated by Parviz Marzban, Forouzanfar publications, Tehran.

Makinejad, M. (2008). History of art of Iran during Islamic period, architectural ornaments, center for research and development of humanities, Tehran.

Hall, J. (2001). Dictionary of symbols in east and west, translated by Roghaye Behzai, Contemporary dictionary, Tehran

Konel, E. (2004). History of Islamic art, translated by Yaghoub Azhand, Mola publications, Tehran

Sarafzadegan, A. (2001). Comparing color and tile during Safavid and Qajar dynasty (Chaharbagh School of Isfahan, Supreme School of Sepahsalar), M.A. Thesis in the field of art research, Faculty of arts and architecture of Teacher Training University

Marzban, P. (1986). Summary of history of art, Organization for publications and education of Islamic Revolution, Tehran

Esmaeil, K., Zahra, S. T. (2015). A Hybrid Face Detection Approach in Color Images with Complex Background",Indian Journal of Science and Technology, 8(1). http://dx.doi.org/10.17485/ijst/2015/v8i1/51337

Alireza, R., Maziar, I., Majid, G., \& Saeed, V. (2015). Investigation of ANN-GA and Modified Perturb and 
Observe MPPT Techniques for Photovoltaic System in the Grid Connected Mode. Indian Journal of Science and Technology, 8(1). http://dx.doi.org/10.17485/ijst/2015/v8i1/54277

Assari, A., \& Mahesh, T. (2011). Demographic comparative in heritage texture of Isfahan city. Journal of Geography and Regional Planning, 4(8), 463.

\section{Copyrights}

Copyright for this article is retained by the author(s), with first publication rights granted to the journal.

This is an open-access article distributed under the terms and conditions of the Creative Commons Attribution license (http://creativecommons.org/licenses/by/4.0/). 